\title{
Homeschooling: an Alternative Education in Indonesia
}

\author{
Achmad Razi ${ }^{1}$ \\ ${ }^{1}$ Postgraduate Program Islamic Management Education Sunan Gunung Djati State Islamic \\ University of Bandung, Indonesia \\ Email: chmdrz11@gmail.com
}

\begin{abstract}
:
This paper aims to examine homeschooling an alternative education in Indonesia. At the present time a lot of popping educational institutions, began formal education through non-formal education. The institute has a goal to educate the future generation. The result, not all educational institutions could be feasible for the education of children today, as in formal education. Often, formal education, structural, and impressed force, make students feel depressed, so they could not undergo the program learning with fun, excitement, and filled with love. Moreover, competition among learners causing some students feel stress so that the child is looking at learning as a liability burden and not as a requirement. In the present era, emerging institutions of alternative education in an effort to address the above issues, one of which is home schooling.
\end{abstract}

Keyword: Education, Home schooling, Educational Institution.

\section{A. INTRODUCTION}

Many parents who are not satisfied with the results of the formal school (Dyson, 2001, Harvard Family Research Project, 2006) encourages parents to educate their children at home (Mangunwijaya, 2008). Often, formal schooling oriented grades (in the school), instead of promoting life skills and social skills (the values of faith and morals). At school, many students pursue grades by cheating (McCabe, Trevino, and Butterfield, 2001) or buy a fake degrees or diploma (Grolleau, Lakhal and Mzoughi, 2008). In addition, the personal attention to the children, lack of attention, plus, stigmatized and child's identity is determined by his friends who are smarter, more superior or more "intelligent". Such circumstances add to the atmosphere of the school to be unpleasant (Cf., Schaps and Solomon, 2003).

The discontent is increasingly sparked parents choose to educate their children at home, with the risk of providing a lot of time and energy (Cf., Patterson, Gibson, Koenigs, Maurer, Ritterhouse, Stckton and Taylor, 2007). Homeschooling became a place of hope parents to improve the quality of children's education (Murray, Handyside, Straka, and Titus, 2013), develop the values of faith/religion and morals as well as get a fun learning environment (Cf., Lie, Andriyono and Prasasti, 2014)

Every parent wants their children get a quality education (Cf., L'Namira, 2009), the values of faith and morals are embedded well, and the atmosphere fun children's learning (Abbas, 1984). Often these things are not found parents in public schools. Hence came the idea of parents to "educate" 
their children at home. In its development, stand school institution called school-house or also known as independent schools, or home education or home based learning (Mountney, 2009).

\section{B. METHODS}

This article will analyze how the phenomenon of home education or home-based learning works; and how the parent's choice uses the opportunity for facilitating their children in basic learning stages. This potential will be developed to the maximum when families facilitate a learning environment that supports students at home so it really felt at home in the learning process. This method is able to avoid negative environmental effects that may be encountered by children in formal schools, promiscuity, brawls, cigarettes and illegal drugs is a scourge that continues to haunt the parents while they are unable to keep an eye on her son every time.

\section{RESULT AND DISCUSSIONS}

\section{Brief History of Homeschooling}

The philosophy of home schooling is people are basically beings learn and enjoy learning (Raja, 2012); we do not need to be shown how to learn. That kills the pleasure of learning are those who seek menyelak, manage, or control (Sumardiono, 2007). Fueled by that philosophy, in the 1960s there was extensive discussion and debate on education schools and school systems. Most of the teachers and observers children and education, said that the students' academic failure is not determined by the lack of effort on the school system, but due to the school system itself (Cf., Legault, Demers and Pelletier, 2006).

At the same time, the end of the 1960s and early 1970s, Raymond and Dorothy Moore conduct research on the tendency for parents to send children to the early childhood education. Their research shows that including children in formal school before the age of 8-12 years is not only ineffective, but actually also be bad for children, particularly children of men because of delays in their maturity (Holt,1995).

After thinking about the failure of the school system received wide response, Holt himself later published other works Instead of Education; Ways to Help People Do Things Better (Holt, 2004). The book also received rave reviews from the homeschooling parents in various parts of the United States. In 1977, Holt publishes a magazine for education at home which is named: Growing Without Schooling.

Similar to Holt, Raymond and Dorothy Moore later became an important supporter and consultant homeschooling. After that, homeschooling continues to grow for various reasons. Apart from the beliefs, the growth of homeschooling too much driven by dissatisfaction with the education system in formal schools (Bunn, 2008).

\section{Homeschooling in Indonesia}

Homeschooling development in Indonesia is not yet known precisely because there has been no specific research on root development. The term homeschooling is a relatively new treasures in Indonesia (Isnawati, 2013). However, if viewed from the concept of homeschooling as learning does not take place in formal school alias self-taught, then the home as a school is not a new thing. Many historical figures Indonesia are already practicing homeschooling as $\mathrm{KH}$. Agus Salim, Ki Hajar Dewantara, and Buya Hamka (Sumardiono, 2007). 
In Indonesia, only a few institutions that hold homeschoooling, such as Morning Star Academy and government agencies in the form of Teaching and Learning Center (CLC). Community Learning Center (CLC) is a government program in education informal channels. Agency CLC organizers are already hundreds in Indonesia (Sarie, 2005).

In South Jakarta wrote, there are about 25 institutions CLC organizers to number approximately 100 students. Each program consists of CLC Program Package A (for elementary school), B (junior high school), and Package $C$ (high school level). CLC is actually organizing the education process for 3 days at school, rest, tutor went to the house the students. The students must take exams in order to obtain a diploma or continuing education to the next level. Differences diploma with public schools, CLC immediately remove it from the center. At present, the development of homeschooling in Indonesia is influenced by access to information that is more open and bring the parents have more options for their children's education.

\section{Definition of Homeschooling}

The term comes from the English Homeschooling means a home school (Harding and Farrell, 2003). Homeschooling take root and grow in the United States (Cf., Kunzman, 2005). Homeschooling also known as home education, home-based learning or independent school. The common understanding is homeschooling education model where a family chooses to be solely responsible for their children's education by using home as a base education (Sumardiono, 2007). Choosing to take responsibility means that parents are involved directly determine the process of education (Fagbeminiyi, 2011) determining the direction and purpose of education (Topor, Keane, Shelton, and Calkins, 2010), the values to be developed (Vermeer, 2014) intelligence and skill (Sanders and Morawska, 2014) curriculum and materials (Olibie, 2014) as well as the methods and practices of learning (Nokali, Bachman, and Drzal, 2010).

The role and commitment of parents are fully demanded. In addition to the selection of materials and home school education standards, they also have to carry out examinations for their children to get a certificate (MolokoMphale and Mhlauli, 2014), with the aim to continue their education to the next level (Baum and Payea, 2005).

\section{Homeschooling in national education}

The Ministry of Education called the school-house in terms of education homeschooling. Pathshome school is categorized as informal education path is the path of education and family environment (article 1 of the Act on National Education System - Sisidiknas No. 20/2003). Informal education activities carried out by families and shaped environmental learning activities independently. Although the government does not regulate the content standards and informal educational service process, but the results of informal education is recognized equal to the formal education (public schools) and non-formal after students pass the exam in accordance with national education standards (Constitution 1945, 2003).

In Act 20 Year 2003 on National Education System, education is a conscious and deliberate effort to create an atmosphere of learning and the learning process so that learners are actively developing the potential for him to have the spiritual power of religion, self-control, personality, intelligence, character and skills needed him, community, nation and state. Also described is the national education system overall educational components are interlinked in an integrated manner to achieve the goals of national education (Constitution 1945, 2003). 
Based on the definition of education and national education system, the home school to be part of efforts in achieving the functions and objectives of the national education develop the skills and character development and civilization of the nation's dignity in the context of the intellectual life of the nation, is aimed at developing students' potentials in order to become a man of faith and fear of God Almighty, noble, healthy, knowledgeable, skilled, creative, independent, and become citizens of a democratic and accountable.

\section{Driver Factors of Homeschooling}

\section{a. Formal school failure}

Both the United States and in Indonesia, the formal school failure in generating a better quality of education becomes a trigger for the families in Indonesia or abroad to conduct homeschooling. Home schooling is assessed able to produce quality education (Cf., Mulyadi, 2010).

\section{b. Multiple intelligence theory}

One of the educational theories influential in the development of homeschooling is the Theory of Multiple Intelligence in the book Frames of Minds: The Theory of Multiple Intelligences was initiated by Gardner (1983, revised edition 2011). Gardner initiated the theory of multiple intelligences. At first, he found the distinction seven types of intelligence (intelligence) human. Then, in 1999, he added two new types of intelligence so that a 9 types of human intelligence. The types of intelligences are: linguistic intelligence; Logical-mathematical intelligence; Intelligencevisual space; Bodily-kinesthetic intelligence; Musical intelligence; Interpersonal intelligence; Intrapersonal intelligence; environmental intelligence; and existential intelligence. Gardner's theory has sparked parents to develop the potentials of intelligence possessed child. Often, formal schooling is not able to develop a child's intelligence, because the formal school system often even limiting a child's intelligence (Gardner and Hatch, 1989)

\section{c. The figure of the famous homeschooling}

Many important figures of the world can succeed in life without going through formal education, have triggered the emergence of homeschooling. The names, Benjamin Franklin, Thomas Edison, $\mathrm{KH}$. Agus Salim, Ki Hajar Dewantara and other figures.

Benjamin Franklin, for example, he managed to become a statesman, scientist, inventor, civic leaders and public servants were not for learning in formal school. Franklin only had two years to attend school because their parents could not afford the cost of education. The rest, he learned about life and various things from time to time in the home and elsewhere that he could make it as a place of learning (Franklin, 1909).

\section{d. The availability of various facilities}

Today, the development of homeschooling participate triggered by growing facility in the real world (Cf., Pearson, 2002). The facilities that include educational facilities (libraries, museums, research institutions), public facilities (parks, stations, roads), social services (parks, orphanages, hospitals), business facilities (malls, exhibitions, restaurants, factories, fields , plantations), and the facilities and information technology (internet and audiovisual). 
From the explanation above, the positive impacts of homeschooling, at least, can be seen as follows (Cf., Smith, 2013): it has accommodated maximum potential intelligence of the child because every child has the diversity and distinctiveness of their interests, talents, and skills. This potential will be developed to the maximum when families facilitate a learning environment that supports students at home so it really felt at home in the learning process. This method is able to avoid negative environmental effects that may be encountered by children in formal schools, promiscuity, brawls, cigarettes and illegal drugs is a scourge that continues to haunt the parents while they are unable to keep an eye on her son every time. By the homeschooling, the child's intelligence will be fully developed because the child is given the freedom to learn. Home schooling gives a lot of flexibility for students to enjoy the learning process. Each homeschooling students are given the opportunity to work directly study the materials provided.

However, Negative Impacts of Homeschooling, al least, also can be seen as follows (Sumardiono, 2009). Children who are less socially has caused them stay away from another children at certain age; Requires a commitment and responsibility of parents; Excessive protection of parents can give side effects inability to resolve the situation and social issues are complex and unpredictable; and Formal school is a typical learning to train children to compete and achieve the highest success (Cf., West, 2009).

\section{Homeschooling vs Formal School}

The educational model of the most famous and recognized community is school or formal education system both held public and private. Public schools are often seen as some people are more valid and preferred. However, for some people, the public school system is a school that is not satisfactory for the development of the child. Public school became the scapegoat for the output of issuance. This can be seen from the output of formal education are becoming criminals, perpetrators of mob justice, politicians are liars and fraudsters big fish. Reasons disappointment that trigger families choose homeschooling as an alias home school alternative education (Cf., Zullig, Huebner and Patton, 2010).

In essence, both homeschooling and formal schools, both as a means to deliver children achieving educational goals as expected. But homeschooling and formal schools have differences. In the formal school system, the education of children is delegated the responsibility of parents to teachers and school administrators. In homeschooling, the responsibility of the education of children rests with the parents (Moreau, 2012). The system of formal school is standardized to meet the needs of children in general, while the homeschooling system tailored to the needs of children and family circumstances. In formal school, learning schedule has been determined and uniform for all students. In homeschooling, the schedule is flexible, it is depend on the agreement between children and parents. Management of formal schooling is done centrally, such as setting and determination of curricula and teaching materials. Management at the homeschooling is decentralized and based on family's wishes. The curriculum and teaching materials have been selected and determined by the parents (Moreau, 2012).

\section{CONCLUSION}

Homeschooling is a choice and an alternative repertoire education for parents in improving the quality of education, developing the value of faith (religion), and want a more pleasant learning atmosphere. On the other hand, there are public schools that provide teaching materials and curriculum centrally and uniformly, in line with expectations and needs of children. Both homeschooling and public schools (formal education) both have advantages and disadvantages in 
delivering learners achieve educational goals. A matter of choice on both of them, it is up to the parents and families in accordance with the conditions of the family. By the homeschooling, the child's intelligence will be fully developed because the child is given the freedom to learn. Home schooling gives a lot of flexibility for students to enjoy the learning process. Each homeschooling students are given the opportunity to work directly study the materials provided. 


\section{References}

Abbas. (1984). "Menguak Tabir Kusam: kumpulan essay permasalahan pendidikan", Surabaya, Bina Ilmu.

Baum, Sandy and Payea, Kathleen. (2005). "The Benefits of Higher Education for Individuals and Society", in Education Pays 2004 Trends in Higher Education Series, (revised edition), The College Board: Connect Students to College Success, (www.collegeboard.com accesed $18^{\text {th }}$ November 2015)

Bunn, Yvonne. (2008). "From the Director of Homeschool Support", in the Virginia Home Educator, Spring.

Fagbeminiyi, Fasina, F. (2011). "The Role of Parents in Early Childhood Education: A Case Study of Ikeja, Lagos State, Nigeria", in Global Journal of Human Social Science Volume 11 Issue 2 Version 1.0, pp. 43-52.

Febriane, Sarie. (2005). "Home Schooling" Model Pendidikan Alternatif, (Kompas Cyber Media, edisi 29 Agustus 2005).

Franklin, Benjamin (1909). The Autobiography of Benjamin Franklin; with Introduction and Notes Edited by Charles W Eliot LId, P F Collier \& Son Company, New York, (downloaded from:https://www4.uwsp.edu/philosophy/dwarren/LOBenFranklin/AutobiographyBenjami nFranklin.pdf)

Gardner, Howard and Hatch, Thomas. (1989). "Multiple Intelligences Go to School: Educational Implications of the Theory of Multiple Intelligences", in Educational Researcher, Vol. 18, No. 8, pp. 4-10

Gardner, Howard. (1983, revised edition 2011). Frames of Mind: The Theory of Multiple Intelligences, New York, Basic Books.

Grolleau, Gilles, Lakhal, Tarik and Mzoughi, Naoufel. (2008). "An Introduction to the Economics of Fake Degrees", in Journal of Economic Issues Vol. 42, No. 3 (Sep., 2008), pp. 673-693, http://dx.doi.org/10.1080/00213624.2008.11507173

Harding, Terry and Farrell, Ann. (2003). "Home Schooling and Legislated Education" in, Australia \& New Zealand Journal of Law \& Education, Vol 8, No 2, 2003, pp. 127 - 135

Holt, John. (1995). How Children Fail, United State (revised edition): Pitman Publishing Company (Original 1964), Paperback.

Holt, John. (2004). Instead of Education: Ways to Help People Do Things Better, Sentient Publications.

Isnawati, Uzlifatul Masruroh. (2013). "Homeschooling: Another Perspective in Global Education" in Jurnal Humaniora Vol 1 No 2.

Kunzman, Robert. (2005). "Homeschooling In Indiana: A Closer Look", in Education Policy Brief: Center for Evaluation and Education Policy, Vol. 3, Number 7, Summer. 
L'Namira, Sylvia. (2009). "Tahzan for Single Mothers: Selalu ada jalan untuk seorang ibu meski ia terbang dengan sebelah sayap": Bandung, Lingkar Pena Publishing House: Mizan.

Legault, Lisa, Demers, Isabelle Green- and Pelletier, Luc. (2006). "Why Do High School Students Lack Motivation in the Classroom? Toward an Understanding of Academic Amotivation and the Role of Social Support", in Journal of Educational Psychology, pp. 567-582, http://dx.doi.org/10.1037/0022-0663.98.3.567

Lie, Anita, Andriyono, Takim and Prasasti, Sarah. (2014). Menjadi Sekolah Terbaik: praktik strategis dalam Pendidikan, Jakarta, Tanoto Foundation.

Mangunwijaya, Forum. (2008). Kurikulum yang Mencerdaskan visi 2030 dan Pendidikan Alternatif, Jakarta, Kompas.

McCabe, Donald L., Trevino, Linda Klebe, and Butterfield, Kenneth D. (2001). Cheating in Academic Institutions: A Decade of Research, in Ethics and Behavior, 11 (3), 2001, Inc., pp. 219-232, http://dx.doi.org/10.1207/S15327019EB1103_2

Moloko, Mphale, Luke and Mhlauli, Mavis B. (2014). An Investigation on Students Academic Performance for Junior Secondary Schools in Botswana", in European Journal of Educational Research Vol. 3, No. 3, pp. 111-127

Moreau, Kathi. (2012). "Home School Vs. Public Schooled: Specific Differences in the Educational Outcomes of those Students who are Home Schooled vs Students in A Traditional School Setting", in https://www.nmu.edu/education/sites/DrupalEducation/files/UserFiles/ Moreau_Kathi_MP.pdf

Mountney, Ros. (2009). Learning without School: Home Education, London and Philadelphia, Jessica Kingslay Publisher.

Mulyadi, Seto. (2010). "Effect of the Psychological Security and Psychological Freedom on Verbal Creativity of Indonesia Homeschooling Students", in International Journal of Business and Social Science Vol. 1 No.2; November, pp. 72-79.

Murray, Mary M., Handyside, Lisa M., Straka, Leslie A. and Titus, Tabatha V. Arton-. (2013). "Parent Empowerment: Connecting with Preservice Special Education Teachers" in School Community Journal, Vol. 23, No. 1, pp. 145-168.

Nokali, Nermeen E. El, Bachman, Heather J., and Drzal, Elizabeth Votruba. (2010). "Parent Involvement and Children's Academic and Social Development in Elementary School", in Child Development, May, pp. 988-1005, http://dx.doi.org/10.1111/j.14678624.2010.01447.x

Olibie, Eyiuche Ifeoma. (2014). "Parental Involvement in Curriculum Implementation as Perceived by Nigeria Secondary School Principals" in Journal of Education and Learning; Vol. 3, No. 1, pp. 40-51, http://dx.doi.org/10.5539/jel.v3n1p40

Patterson, Jean A., Gibson, lan, Koenigs, Andrew, Maurer, Michael, Ritterhouse, Gladys, Stockton, Charles and Taylor, Mary Jo. (2007). "Resisting Bureaucracy: A Case Study of 
Home Schooling", in Journal of Thought, Fall-Winter, pp. 71-86 http://dx.doi.org/10.2307/jthought.42.3-4.71

Pearson, Richard C. (2002). "The Worth of a Child: Rural Homeschooling/Public School Partnerships Are Leading the Way", in http://files.eric.ed.gov/fulltext/ED464788.pdf

Raja, Colleen. (2012). "A Personal Journey into Home Learning" in Journal of Unschooling and Alternative Learning, Vol. 6 Issue 12, pp. 1-29.

Sanders, Matthew R. and Morawska, Alina. (2014). "Can Changing Parental Knowledge, Dysfunctional Expectations and Attributions, and Emotion Regulation Improve Outcomes for Children?" in Encyclopedia on Early Childhood Development (http://www.childencyclopedia.com/parenting-skills/according-experts/can-changing-parental-knowledgedysfunctional-expectations-and, accesed $12^{\text {th }}$ December 2015)

Schaps, Eric and Solomon, Daniel. (2003). "The Role of the School's Social Environment in Preventing Student Drug Use", in The Journal of Primary Prevention, Vol. 23, No. 3, Spring, pp. 299-328, http://dx.doi.org/10.1023/A:1021393724832

Smith, Wade Clay. (2013). "The Decision to Home School Children: Primary Parental and Student Motivators", in Journal of Education and Learning. Vol.7 (3) pp. 173-178, http://dx.doi.org/10.11591/edulearn.v7i3.182

Sumardiono. (2007). "Homeschooling, Lompatan Cara Belajar", (Jakarta: PT. Elex Media Komputindo.

Topor, David R., Keane, Susan P., Shelton, Terri L. and Calkins, Susan D. (2010). "Parent Involvement and Student Academic Performance: A Multiple Mediational Analysis", in Journal of Prevention \& Intervention in the Community, Volume 38, 2010 - Issue 3, pp. 183-197, http://dx.doi.org/10.1080/10852352.2010.486297

Undang-Undang RI No. 20 Tahun 2003 tentang Sistem Pendidikan Nasional.

Vermeer, Paul. (2014). "Religion and Family Life: An Overview of Current Research and Suggestions for Future Research", in Religions, 5, pp. 402-421; http://dx.doi.org/10.3390/rel5020402

West, Robin L. (2009). "The Harms of Homeschooling", in Philosophy \& Public Policy Quarterly, Vol. 29, No. 3/4 (Summer/Fall).

Wresti ,Clara. (2005). "Rumah Kelasku, Dunia Sekolahku", Harian Kompas, edisi 13 Maret.

Zullig, Keith J., Huebner, E. Scott, and Patton, Jon M. (2010). "Relationships among School Climate Domains and School Satisfaction", in Psychology in the Schools, Vol. 48 (2), 2011, pp, 133-145, http://dx.doi.org/10.1002/pits.20532 
Homeschooling: an Alternative Education in Indonesia 